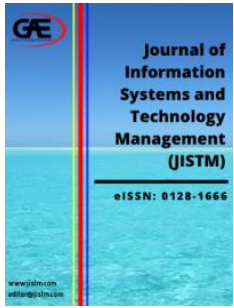

\author{
JOURNAL OF INFORMATION \\ SYSTEM AND TECHNOLOGY \\ MANAGEMENT (JISTM) \\ WWW.jistm.com
}

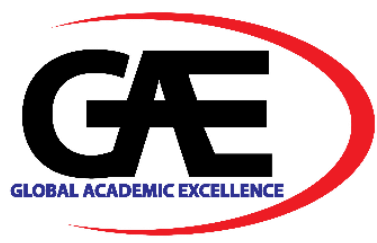

\title{
THE POTENTIAL OF OFFSHORE WIND ENERGY IN THE EAST COAST OF PENINSULAR MALAYSIA, TERENGGANU
}

\author{
Mat Nizam Uti ${ }^{1 *}$, Ami Hassan Md Din ${ }^{1,2^{*}}$, Norhakim Yusof ${ }^{3}$, Omar Yakob $^{4}$, \\ 1 Geospatial Imaging and Information Research Group (G12RG), Universiti Teknologi Malaysia, Malaysia \\ Email: mnizam65@graduate.utm.my \\ 2 Geosciences and Digital Earth Centre (INSTEG), Universiti Teknologi Malaysia, Malaysia \\ Email: amihassan@utm.my \\ 3 Department of Geoinformation, Universiti Teknologi Malaysia, Malaysia \\ Email: norhakim@utm.my \\ $4 \quad$ School of Mechanical Engineering, Universiti Teknologi Malaysia, Malaysia \\ Email: omaryaakob@utm.my \\ Corresponding Author
}

\section{Article Info:}

\section{Article history:}

Received date: 01.10 .2021

Revised date: 01.11.2021

Accepted date: 20.11.2021

Published date: 01.12.2021

\section{To cite this document:}

Uti, M. N., Din, A. H. M., Yusof, N., \& Yaakob, O. (2021). The Potential Of Offshore Wind Energy In The East Coast Of Peninsular Malaysia, Terengganu. Journal of Information System and Technology Management, 6 (24), 200-212.

\section{DOI: $10.35631 / J I S T M .624020$}

This work is licensed under CC BY 4.0

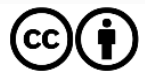

\begin{abstract}
:
A detailed understanding of wind characteristics is very important for offshore wind energy development. A 26 years of wind speed data (1993-2018) were retrieved using Radar Altimeter Database System (RADS) to assess the potentiality of offshore wind energy in Terengganu waters. Seasonal assessment and wind energy density derivation was carried out to choose the potential location for wind energy development. This study highlights the multi-criteria site suitability analysis using Analytical Hierarchy Process (AHP) and is supported by the geographical information system (GIS) by developing a suitability map. The site suitability analysis considered a few criteria, such as seasonal assessment, physical, environmental, and wind resources. Theoretically, the Terengganu area possessed strong wind during the Northeast monsoon with an average of $3.46 \mathrm{~m} / \mathrm{s}$ and experienced up to 6 $\mathrm{m} / \mathrm{s}$ during this monsoon. For offshore areas, which is more than $50 \mathrm{~km}$ from the coastline, Terengganu waters experienced a maximum of wind speed more than $5 \mathrm{~m} / \mathrm{s}$ and the average wind power density varied from $40 \mathrm{~W} / \mathrm{m} 2$ to $60 \mathrm{~W} / \mathrm{m} 2$. While Tenggol Island possessed a maximum wind speed between $3 \mathrm{~m} / \mathrm{s}$ to $5 \mathrm{~m} / \mathrm{s}$ and produce up to $40 \mathrm{~W} / \mathrm{m} 2$ of average wind energy density. From the suitability analysis, a few areas are identified as the potential location with an optimum resource of wind energy. Even though, Malaysia is located at low wind area, this research will help organisation or governments to plan suitable technology and policy for harvesting wind energy.
\end{abstract}


Keywords:

GIS, Altimeter, Site Suitability Analysis, Wind Speed, Wind Energy Density

\section{Background of Study}

Since 1999, Malaysia has introduced the five-fuel energy strategy as a main resource, which is natural gas, coal, oil, hydro and renewable energy mix. Three main renewable energy, namely solar energy, wind energy and ocean energy (Hashim, 2016). These energies provide for long term energy consumption as long as the oceans are preserved. The ocean energy sector also provides outstanding opportunities to contribute to the production of low carbon renewable energy around the world. In assessing the offshore wind energy resources, the main parameter is the wind speed data. In Malaysia, other than open sources data, meteorological department play important role in providing wind speed data but limited to inland areas only. According to Yaakob et al (2016), due to limited of buoy measurement in both number and spatial distribution, making satellite altimeter reliable to use over the ocean areas, especially in Malaysian seas as shown in Figure 1.

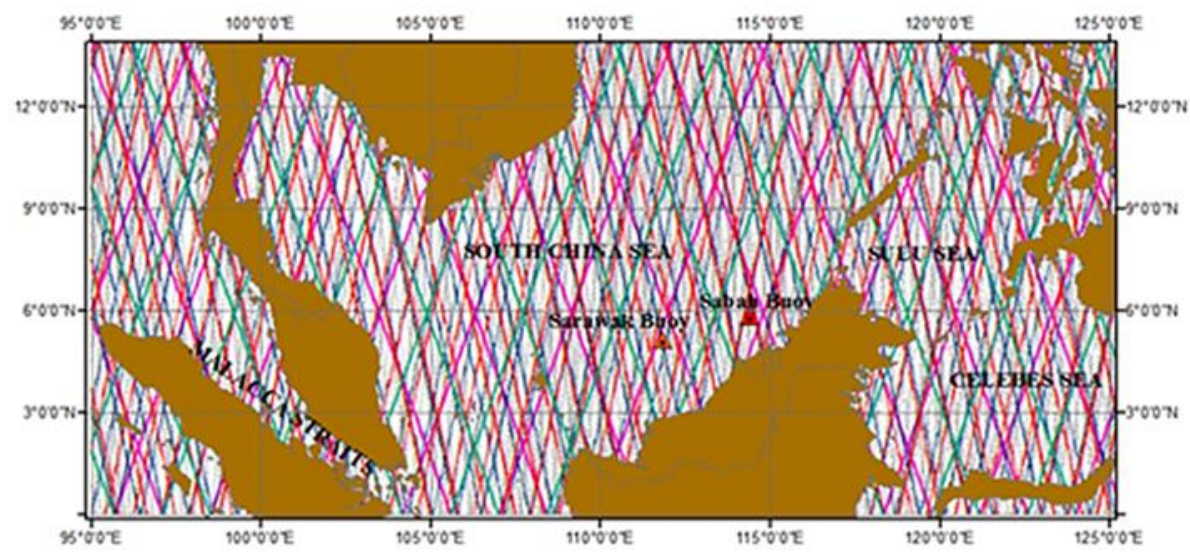

Figure 1: Satellite Altimeter Mission Over Malaysian Seas

Source: (Yaakob et al. (2016))

\section{Satellite Altimeter}

Almost 30 years since the first altimeter TOPEX/Poseidon launched, ocean exploration has grown the world. According to Aziz et al (2014), satellite altimeter is proven to provide ocean information such as wind speed, significant wave height and sea level. Satellite altimeter is able to provide long-term datasets which support researchers to study the ocean environment. The basic principle of satellite altimeter is referred to the reflected pulse from the surface and backscattered of the wind and waves. Then, the pulse is received by altimeter sensor in a few milliseconds. There are several parameters for altimeters which are returned signal from the sea; slant of the reflected signal; distance, $d$ from the sea level (measured by the time travel of the pulse); wind speed determination by the power from the impulse response (Aziz et al, 2014) as shown in Figure 2. 
Source: (Traon et al. (2015))

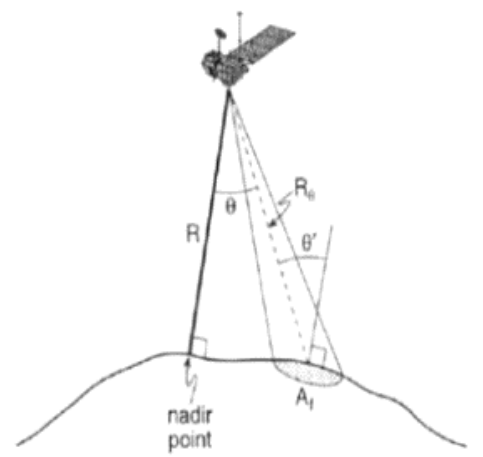

Figure 2: Altimeter Principle

Corrections were applied to the signal or altimeter range such as clock drift, antenna phase centre, time, Doppler shift and atmospheric correction due to tropospheric and ionospheric effect as explained in Equation 1.

where,

$$
R_{\text {corrected }} R_{\text {obs }}-\Delta R_{\text {dry }}-\Delta R_{\text {wet }}-\Delta R_{\text {iono }}-\Delta R_{\text {ssb }}
$$

$R_{o b s}=c^{t} / 2$ is the computed range from the tavel time, $t$, and $c$ is the speed of the radar pulse $\Delta R_{d r y}=$ Tropospheric correction (Dry)

$\Delta R_{\text {wet }}=$ Tropospheric correction (Wet)

$\Delta R_{\text {iono }}=$ Ionospheric correction

$\Delta R_{s s b}=$ Tropospheric correction (Sea-state bias correction)

\section{Data and Methods}

\section{Radar Altimeter Database System Using RADS}

Wind speed dataset is available in various form, which include instrumental observations, visible measurement, in-situ (buoy) and also satellite-based measurement. According to Hashim et al (2020), buoy can provide the most accurate data because it can provide direct observation. But, due to the limited of buoy stations in Malaysia waters has curb the effort for ocean energy study. However, through years satellite altimeter has provided a reliable measurement for ocean monitoring, environmental changes and even marine energy resources. This is because, satellite altimeter served accurate data worthy of temporal and spatial coverage.

Many studies have proven that satellite altimeter information is reliable to use, for example a study by Kumar et al (2015), concluded that the wind speed derived from the SARAL/Altika mission correlated well with buoy with correlation coefficient of 0.91 , and RMSE of $1.13 \mathrm{~m} / \mathrm{s}$ in the North Indian Ocean. While, a study by Uti et al. (2017) also proved that satellite altimeter has good correlation with buoy data with coefficient of 0.8 in Malaysian waters. This study, has occupied multi-mission satellite altimeter that include TOPEX/Poseidon, Jason-1, Jason2, Jason-3, ERS-1, ERS-2, ENVISAT1, Cryosat2 and Sentinel-3a to gain the wind speed data. This data obtained using the Radar Altimeter Database System (RADS) that operates within the Netherlands Earth Observation NETwork. This system provides an integrated, approved 
and calibrated sea level directory from multi-mission altimeter and enables users to access, process and validate the altimeter data. Thus, 26 years (1993-2018) of wind speed daily, monthly and climatology data were retrieved from this system for the validation and seasonal variability assessment. Figure 3 presents the general framework of data retrieval from RADS.

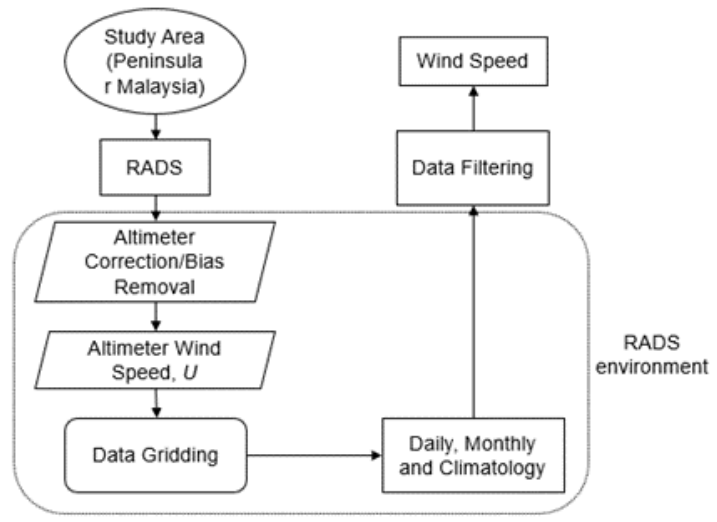

Figure 3: Data Retrieval from Radar Altimeter Database System (RADS)

\section{Multi-criteria Site Suitability Analysis}

To produce a site suitability map, the study approach is divided into two parts, which include the Analytical Hierarchy parts and spatial assessment. The selection of potential sites is a complex decision and requires large cost, manpower and infrastructure (Solangi et al. 2018). Besides, it is necessary the location to be evaluated on important elements such as environmental, physical properties, technical and social factor (Lozano et al. 2014). Table 1 presents the list of wind energy studies in Malaysia.

Table 1: Previous Study of Wind Energy in Malaysia

\begin{tabular}{cccc}
\hline Author & Description & AHP & Spatial analysis \\
\hline $\begin{array}{c}\text { Lee et al } \\
(2009)\end{array}$ & Selection suitable wind farm & $\begin{array}{c}\text { Yes with BOCR } \\
\text { analysis }\end{array}$ & No \\
\hline $\begin{array}{c}\text { Albani et } \\
\text { al (2013) }\end{array}$ & $\begin{array}{c}\text { Feasibility study of offshore } \\
\text { wind energy in Kijal, Malaysia }\end{array}$ & No & No \\
\hline $\begin{array}{c}\text { Hashim } \\
\text { et al }\end{array}$ & $\begin{array}{c}\text { Offshore wind energy resource } \\
\text { assessment in Malaysia }\end{array}$ & No & $\begin{array}{c}\text { Only mapping of } \\
\text { conflicting areas }\end{array}$ \\
$(2020)$ & & & \\
\hline
\end{tabular}

Therefore, to accomplish the site suitability analysis a detailed of criteria analysis is performed using the Analytical Hierarchy Process (AHP) to support the spatial analysis for the site selection

\section{Analytical Hierarchy Process (AHP)}

Analytical Hierarchy Process (AHP) is a structured model use for multi-criteria decision making. This technique was developed by Thomas L. Saaty in 1980, and widely used for site selection. This method provides a comprehensive procedure to evaluate the elements and finalising a constructed weightage of each of the elements. AHP method comprises procedure involved in generating AHP model which is explained below. 


\section{Criteria Listing}

There are many different ways to gather the criteria information. One of the ways is through a questionnaire survey (Aminu at al. 2017). But this study conducts a criterion listing through literature review from the past study. A weightage based on the criteria as shown in Table 2 was generated from AHP method

\section{Pairwise Comparison Matrix}

The pairwise comparison matrix is obtained through a scale 1-9 point as shown in Table 2 . The pairwise comparison matrix will be presented in $(n \times n)$, where $n$ refer to number of criteria.

Table 2: Saaty Pairwise Comparison Scale

\begin{tabular}{cc}
\hline Values & Descriptions \\
\hline 1 & Equally important factors \\
\hline 3 & Moderate important \\
\hline 5 & Strongly important \\
\hline 9 & Very strongly important \\
\hline Reciprocals $\left(\frac{\mathbf{1}}{\boldsymbol{n}}\right)$ & Extremely important \\
\hline
\end{tabular}

Source: (Saaty (1980))

\section{Normalized Pairwise Comparison Matrix}

The normalized value is obtained through calculation of sum of the column, dividing the value of each matrix with the obtained sum of column and calculating the average of the rows to generate the relative weights. In this step, Eigen vector, maximum Eigen value $\left(\lambda_{\max }\right)$ is obtained.

\section{Calculation of Consistency Index (CI) and Consistency Ration (CR)}

This value will represent how good the pairwise calculation in obtaining the weightage that will be used in spatial analysis. Consistency index can be calculated using Equation 2.

$$
C I=\frac{\lambda_{\max }-1}{n-1}
$$

Consistency ratio (CR) can be calculated by dividing the consistency index with random index as shown in Table 3.

Table 3: Random Index Value

\begin{tabular}{cc}
\hline Number of criteria $(\boldsymbol{n})$ & Random Index \\
\hline 1 & 0.00 \\
\hline 2 & 0.00 \\
\hline 3 & 0.58 \\
\hline 4 & 0.90 \\
\hline 5 & 1.12 \\
\hline 6 & 1.24 \\
\hline 7 & 1.32 \\
\hline 8 & 1.41 \\
\hline 9 & 1.45 \\
\hline 10 & 1.49 \\
\hline
\end{tabular}


Source: (Saaty (1980))

11

1.51

According to Tegou et al. (2010), if the consistency ratio (CR) value more than $10 \%$ or 0.10 , the judgements of the criteria based on the pairwise comparison indicates inconsistency. Thus, a re-evaluation of the criteria needs to be done.

\section{Spatial Assessment}

Spatial assessment is an analysis to determine the suitable and potential areas for the wind farm development. The procedure involved with adapting the generated weightage value from AHP, analysing and selecting the best location for offshore wind energy. Two models were produced which include the restriction mode and resources model. The models were produced and layered using spatial analyst tools and Model Builder in ArcGIS 10.3 software. To choose the potential location, suitable criteria were considered with respect to environmental, physical, socioeconomic and resource aspects.

To produce the restriction model, boundaries of each criterion is applied to the model. The boundaries will create a buffer around the elements. The boundary was expressed in linguistic terms such as about $x \mathrm{~km}$ far from, at least $x \mathrm{~km}$, close to $x$, etc (Lyimo et al, 2020) as explained in table 4. This buffer represents an exclusion for the wind farm development. Apart from that, all the spatial processing will be mask inside the Exclusive Economic Zone (EEZ). For suitability model, a Euclidean distance of each of the criteria is performed, this Euclidean distance is applied to the criteria. During the weightage overlay, the obtained weightage from AHP will be used. Suitability model is generated by combining the restriction model with the Euclidean distance.

Table 4: Limitation or Boundaries for Each Criteria

\begin{tabular}{|c|c|c|c|}
\hline No & Aspects & Criteria & Buffer \\
\hline \multirow{3}{*}{$\mathbf{1}$} & \multirow{3}{*}{ Environmental } & Marine protected areas & $3 \mathrm{~km}$ (Hong and Moller, 2011) \\
\hline & & National marine parks & $3 \mathrm{~km}$ (Hong and Moller, 2011) \\
\hline & & Coral reefs & $3 \mathrm{~km}$ (Hong and Moller, 2011) \\
\hline \multirow[t]{4}{*}{2} & \multirow[t]{4}{*}{ Physical } & Underwater Pipelines & $\begin{array}{l}250 \mathrm{~m} \text { on either side of the pipeline was } \\
\text { considered as an exclusion area (Hashim, } \\
\text { 2016) }\end{array}$ \\
\hline & & Underwater Cables & $\begin{array}{c}500 \mathrm{~m} \text { on either side of the pipeline was } \\
\text { considered as an exclusion area (Hashim, } \\
\text { 2016) }\end{array}$ \\
\hline & & Bathymetry & $\begin{array}{l}\text { A depth over } 60 \mathrm{~m} \text { is excluded, to avoid } \\
\text { high installation costs (Vagiona and } \\
\text { Kamilakis, 2018) }\end{array}$ \\
\hline & & Shipping lanes & $\begin{array}{l}\text { The lane was considered as an exclusion } \\
\text { area }\end{array}$ \\
\hline \multirow[t]{4}{*}{3} & \multirow[t]{4}{*}{ Socioeconomic } & $\begin{array}{l}\text { Exploration contacts } \\
\text { areas }\end{array}$ & $\begin{array}{c}\text { The exploration contacts areas classified } \\
\text { as limiting zones (Hashim, 2016) }\end{array}$ \\
\hline & & Fisheries & $\begin{array}{c}50 \mathrm{~km}-150 \mathrm{~km} \text { (Lembaga Kemajuan } \\
\text { Ikan Malaysia) }\end{array}$ \\
\hline & & Oil and gas areas & 15 km (Rahim, 2011) \\
\hline & & Shoreline & $5 \mathrm{~km}$ (Oskamp et al, 2010) \\
\hline
\end{tabular}


Volume 6 Issue 24 (December 2021) PP. 200-212 DOI: $10.35631 / J I S T M .624020$

\begin{tabular}{|c|c|c|c|}
\hline \multicolumn{4}{|c|}{ Port } \\
\hline 4 & Resources & $\begin{array}{l}\text { Wind energy density } \\
\text { (theoretically) }\end{array}$ & $\begin{array}{l}\text { Describe using the wind energy resources } \\
\text { mapping }\end{array}$ \\
\hline
\end{tabular}

As the issue of natural resources and fuel depletion is gaining global attention, through sustainable development initiatives, Malaysia has conducted numerous studies using this method to determine the potential of ocean wave, offshore wind and tidal energy development in Malaysia. For example, a study by Rahim (2011), using the fuzzy logic technique found that east coast of Peninsular Malaysia has $61 \%$ suitability for wave energy, and most of them located at the offshore areas. A study Hashim et al (2020), proved that Borneo Water have potential of offshore wind energy resources with $500 \mathrm{kWh} / \mathrm{m}^{2}$ of annual wind energy density. Even though site suitability analysis is not performed, but this study has considered physical, socioeconomic and environmental as constraints for wind energy development.

\section{Main Results}

\section{Wind Speed Validation}

Generally, buoy data were used as a ground-truth to assess the reliability of altimeter data, this is because buoy data can provide information from direct measurement. Figure 4 shows the comparison of wind speed altimeter and wind speed buoy at Dulang, Terengganu. Based on Figure 4, the trend graph illustrated the wind speed from both altimeter and buoy is slightly the same, but most of the time, the measurement of altimeter is underestimated compare to the buoy. But, the root mean square error is $\pm 0.08 \mathrm{~m} / \mathrm{s}$, while the correlation is 0.60 .

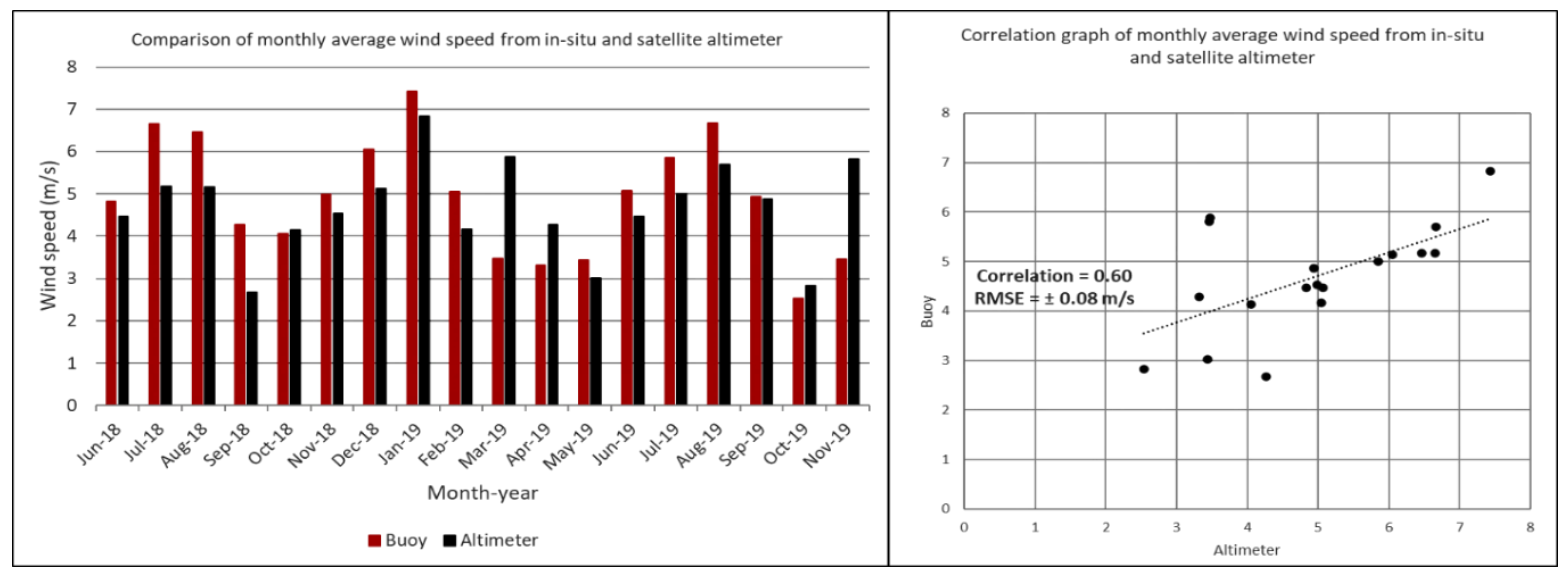

Figure 4: Comparison of Monthly Average Wind Speed from In-situ and Satellite Altimeter and the RMSE and Correlation Value

\section{Seasonal Assessment}

\section{Wind Power Density}

Malaysia experienced with two major monsoon that happened on November to February (northeast monsoon) and May to August (southwest monsoon). The variation of the wind is depending on the movement of the wind from northern hemisphere to southern hemisphere and vice versa. Henceforth, seasonal variability is crucial in order to assess the potential site for offshore wind energy resource. Figure 5 (a) illustrates the average of power density $\left(\mathrm{W} / \mathrm{m}^{2}\right)$ during the northeast monsoon. Theoretically, Terengganu area within $50 \mathrm{~km}-100 \mathrm{~km}$ from coastlines can harvest up to $50 \mathrm{~W} / \mathrm{m}^{2}$ of wind power density. But during the southwest monsoon Copyright (C) GLOBAL ACADEMIC EXCELLENCE (M) SDN BHD - All rights reserved 
Volume 6 Issue 24 (December 2021) PP. 200-212 DOI: 10.35631/JISTM.624020

the wind speed is gradually decrease hence, the east coast of Terengganu can only harvest up to $35 \mathrm{~W} / \mathrm{m}^{2}$ of wind power density. Based on wind speed seasonal assessment conducted by Uti et al. (2013), concluded that Terengganu area possessed with stronger wind during Northeast monsoon compared to other areas.
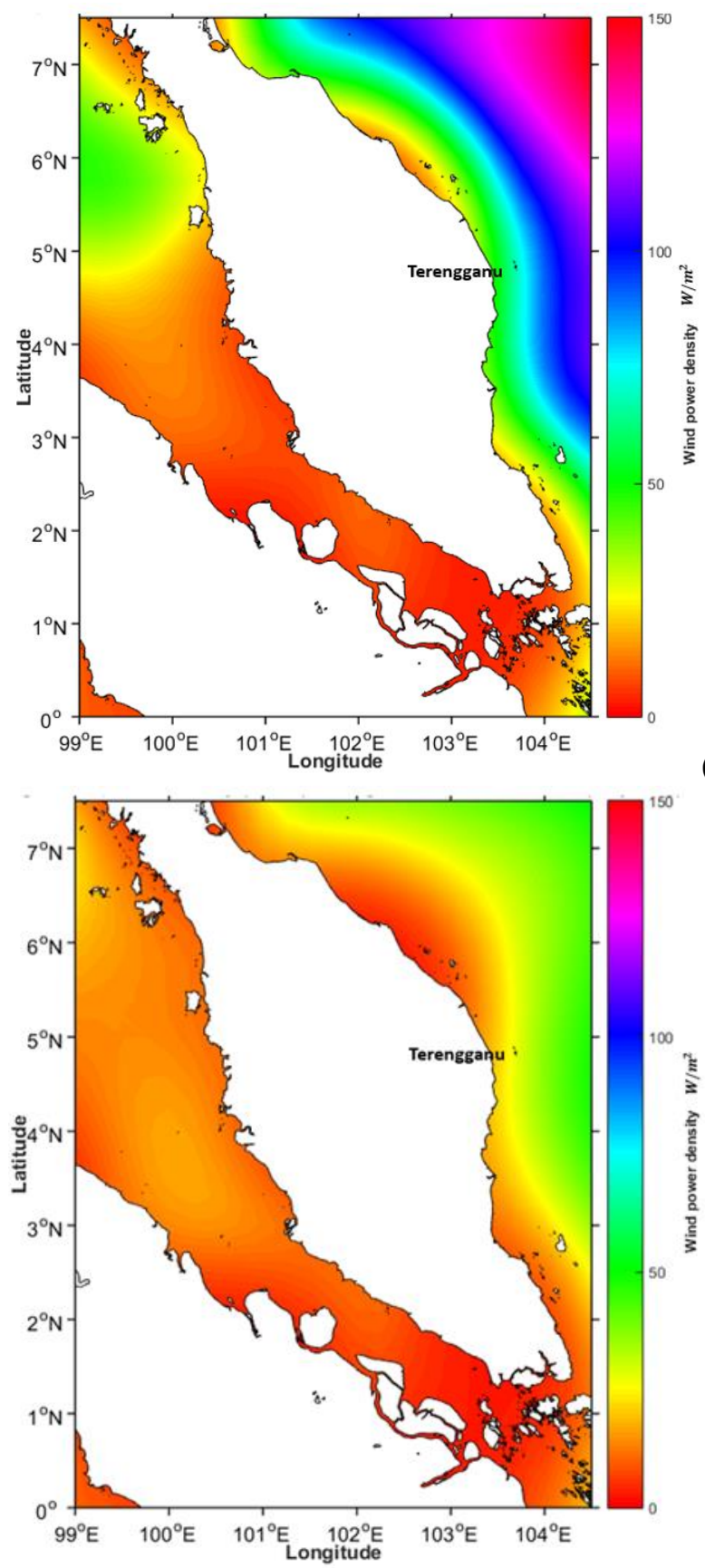

(a)

Figure 5: Average of Wind Power Density $\left(\mathrm{W} / \mathrm{m}^{2}\right)$ during Northeast Monsoon (a) and Southwest Monsoon (b) for 26 Years

\section{AHP and Spatial Analysis Results}

As mentioned before, the important of AHP technique is to support the site selection by finalize the obtained weightage to be used in spatial assessment. Table 5 and Table 6 present that pairwise and normalized pairwise of the criteria. 
Volume 6 Issue 24 (December 2021) PP. 200-212 DOI: 10.35631/JISTM.624020

Table 5: Pairwise Comparison Matrix

\begin{tabular}{|c|c|c|c|c|c|c|c|c|c|c|c|}
\hline Criteria & EEZ & PT & $\mathrm{CO}$ & OG & FL & SC & $\mathbf{U P}$ & NMP & MPA & ECA & SL \\
\hline EEZ (EEZ) & 1 & 7 & 7 & 5 & 7 & 5 & 5 & 5 & 5 & 1 & 3 \\
\hline Port (PT) & 0.14 & 1 & 0.33 & 0.2 & 1 & 0.2 & 0.2 & 0.33 & 0.33 & 0.14 & 0.2 \\
\hline $\begin{array}{l}\text { Coastline } \\
\text { (CO) }\end{array}$ & 0.14 & 3 & 1 & 0.33 & 3 & 0.33 & 0.33 & 0.33 & 0.33 & 0.2 & 0.33 \\
\hline $\begin{array}{l}\text { Oil and } \\
\text { Gas Field } \\
(\mathrm{OG})\end{array}$ & 0.2 & 5 & 3 & 1 & 5 & 1 & 1 & 3 & 3 & 0.33 & 0.33 \\
\hline $\begin{array}{l}\text { Fish main } \\
\text { landing } \\
\text { point }(\mathrm{FL})\end{array}$ & 0.14 & 1 & 0.33 & 0.2 & 1 & 0.2 & 0.2 & 0.2 & 0.2 & 0.2 & 0.2 \\
\hline $\begin{array}{c}\text { Submarine } \\
\text { Cables } \\
(\mathrm{SC})\end{array}$ & 0.2 & 5 & 3 & 1 & 5 & 1 & 1 & 3 & 3 & 0.33 & 1 \\
\hline $\begin{array}{c}\text { Underwater } \\
\text { Pipelines } \\
\text { (UP) }\end{array}$ & 0.2 & 5 & 3 & 1 & 5 & 1 & 1 & 3 & 3 & 0.33 & 1 \\
\hline $\begin{array}{l}\text { National } \\
\text { Marine } \\
\text { Parks } \\
\text { (NMP) }\end{array}$ & 0.2 & 3 & 3 & 0.33 & 5 & 0.33 & 0.33 & 1 & 1 & 0.2 & 0.2 \\
\hline $\begin{array}{l}\text { Marine } \\
\text { Protected } \\
\text { Areas } \\
\text { (MPA) }\end{array}$ & 0.2 & 3 & 3 & 0.33 & 5 & 0.33 & 0.33 & 1 & 1 & 0.2 & 0.2 \\
\hline $\begin{array}{c}\text { Exploration } \\
\text { Contact } \\
\text { Areas } \\
\text { (ECA) }\end{array}$ & 1 & 7 & 5 & 3 & 5 & 3 & 3 & 5 & 5 & 1 & 5 \\
\hline $\begin{array}{l}\text { Shipping } \\
\text { Lane (SL) }\end{array}$ & 0.33 & 5 & 3 & 3 & 5 & 1 & 1 & 5 & 5 & 0.2 & 1 \\
\hline
\end{tabular}


Volume 6 Issue 24 (December 2021) PP. 200-212 DOI: $10.35631 /$ JISTM.624020

Table 6: Normalized Pairwise Comparison Matrix and Consistency Ratio Value

\begin{tabular}{|c|c|c|c|c|c|c|c|c|c|c|c|c|c|}
\hline Criteria & EEZ & PT & $\mathrm{CO}$ & OG & FL & SC & UP & NMP & MPA & ECA & SL & $\begin{array}{l}\text { Criteria } \\
\text { Weights }\end{array}$ & $\begin{array}{l}\text { Criteria } \\
\text { ranks }\end{array}$ \\
\hline EEZ & 0.2658 & 0.1556 & 0.2211 & 0.3247 & 0.1489 & 0.3731 & 0.3731 & 0.1861 & 0.1861 & 0.2414 & 0.2406 & 0.246958235 & 1 \\
\hline PT & 0.0380 & 0.0222 & 0.0105 & 0.0130 & 0.0213 & 0.0149 & 0.0149 & 0.0124 & 0.0124 & 0.0345 & 0.0160 & 0.019107001 & 11 \\
\hline $\mathrm{CO}$ & 0.0380 & 0.0667 & 0.0316 & 0.0216 & 0.0638 & 0.0249 & 0.0249 & 0.0124 & 0.0124 & 0.0483 & 0.0267 & 0.033752189 & 9 \\
\hline OG & 0.0532 & 0.1111 & 0.0947 & 0.0649 & 0.1064 & 0.0746 & 0.0746 & 0.1117 & 0.1117 & 0.0805 & 0.0267 & 0.082737008 & 6 \\
\hline FL & 0.0380 & 0.0222 & 0.0105 & 0.0130 & 0.0213 & 0.0149 & 0.0149 & 0.0074 & 0.0074 & 0.0483 & 0.0160 & 0.019458596 & 10 \\
\hline SC & 0.0532 & 0.1111 & 0.0947 & 0.0649 & 0.1064 & 0.0746 & 0.0746 & 0.1117 & 0.1117 & 0.0805 & 0.0802 & 0.087598456 & 4 \\
\hline UP & 0.0532 & 0.1111 & 0.0947 & 0.0649 & 0.1064 & 0.0746 & 0.0746 & 0.1117 & 0.1117 & 0.0805 & 0.0802 & 0.087598456 & 5 \\
\hline NMP & 0.0532 & 0.0667 & 0.0947 & 0.0216 & 0.1064 & 0.0249 & 0.0249 & 0.0372 & 0.0372 & 0.0483 & 0.0160 & 0.048282513 & 7 \\
\hline MPA & 0.0532 & 0.0667 & 0.0947 & 0.0216 & 0.1064 & 0.0249 & 0.0249 & 0.0372 & 0.0372 & 0.0483 & 0.0160 & 0.048282513 & 8 \\
\hline ECA & 0.2658 & 0.1556 & 0.1579 & 0.1948 & 0.1064 & 0.2239 & 0.2239 & 0.1861 & 0.1861 & 0.2414 & 0.4011 & 0.212989065 & 2 \\
\hline SL & 0.0886 & 0.1111 & 0.0947 & 0.1948 & 0.1064 & 0.0746 & 0.0746 & 0.1861 & 0.1861 & 0.0483 & 0.0802 & 0.113235969 & 3 \\
\hline Sums & 1 & 1 & 1 & 1 & 1 & 1 & 1 & 1 & 1 & 1 & 1 & 1 & \\
\hline
\end{tabular}

Consistency Index and Consistency Ratio

\begin{tabular}{|l|l|}
\hline Information & 11.96805204 \\
\hline Eigen Value & 0.096805204 \\
\hline Consistency Index & 1.51 \\
\hline Random Index & $\mathbf{0 . 0 6 4 0 3 7 3 1 2}$ \\
\hline Consistency Ratio
\end{tabular}


Volume 6 Issue 24 (December 2021) PP. 200-212 DOI: 10.35631/JISTM.624020

Based on the AHP results, the final weightage and the criteria ranking is presents in Table 6 . The most priority criteria are Exclusive Economic Zone with value of weightage 0.246958235 , meaning that the site should be in the EEZ boundary. While, the lowest rank is Port value of 0.019107001 . The consistency ratio indicates the weightage calculation is consistence.

\section{Restriction Model}

The exclusion of the distances for each of the criterion is carried out. The exclusion of the areas is based on the experts' view and literature review as shown in Table 4. A raster data is formed using ArcMap to produce a closed-polygon that illustrates the exclusion buffer for each aspect. The idea is to prevent any potential location inside the conflicting areas as shown in Figure 6.

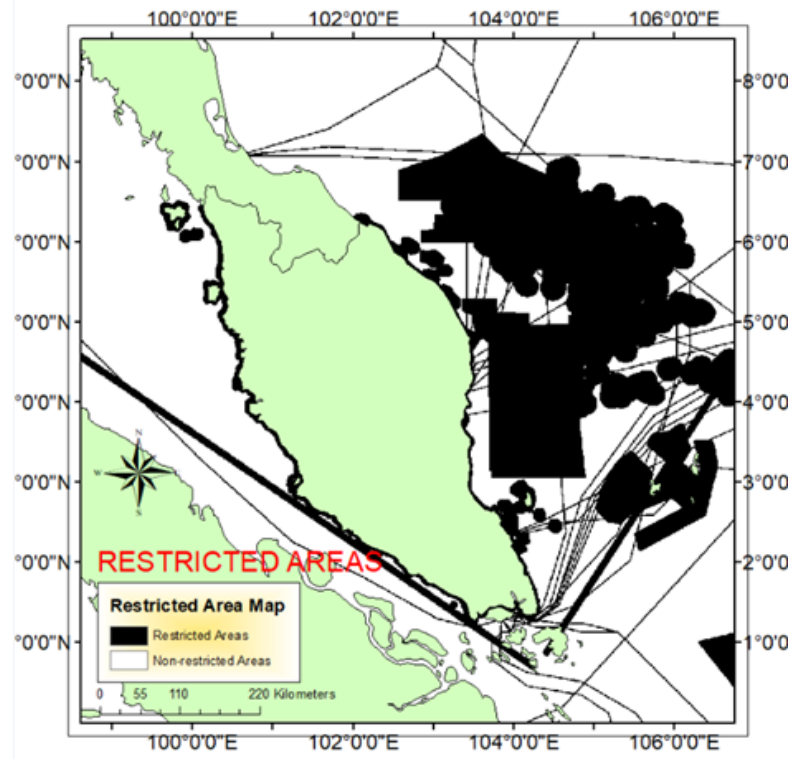

Figure 6: Restriction Model

\section{Resources Model}

Resources model is produced based on the average wind power density $\left(\mathrm{W} / \mathrm{m}^{2}\right)$ during the northeast and southwest monsoon. As stated at Subsection 3.2.1, the average of wind power density is high during the northeast monsoon compare to southwest monsoon. Figure 7 presents the location of offshore wind energy resource with scale of very low to high energy resources. Based on the Figure 7, indicates that coastal areas $(10-50 \mathrm{~km})$ of the Terengganu have very low energy compare to offshore area which is more than $150 \mathrm{~km}$ from the coasts due to low wind speed range. The geographical location Malaysia also affects the capabilities of Malaysia to develop wind energy especially in the coastal areas. But some researchers have suggested that low energy resources should accommodate with suitable turbine for the energy conversion.

According to Briggs (2012), many areas in South East Asia claimed to be experienced with lower wind speed. Thus, he suggested that a smaller turbine with range $1 \mathrm{~kW}$ should be used for low wind speeds region. Most turbines were designed for high wind speed which is $10 \mathrm{~m} / \mathrm{s}$. To optimize the energy generation for lower wind, he suggested that the turbine design should account the smaller blade, airfoil share, construction and bearing friction. Some researchers also proposed the using of a smaller blade for low wind areas, Smith et al. (2011); Yunhao et al. (2021). 


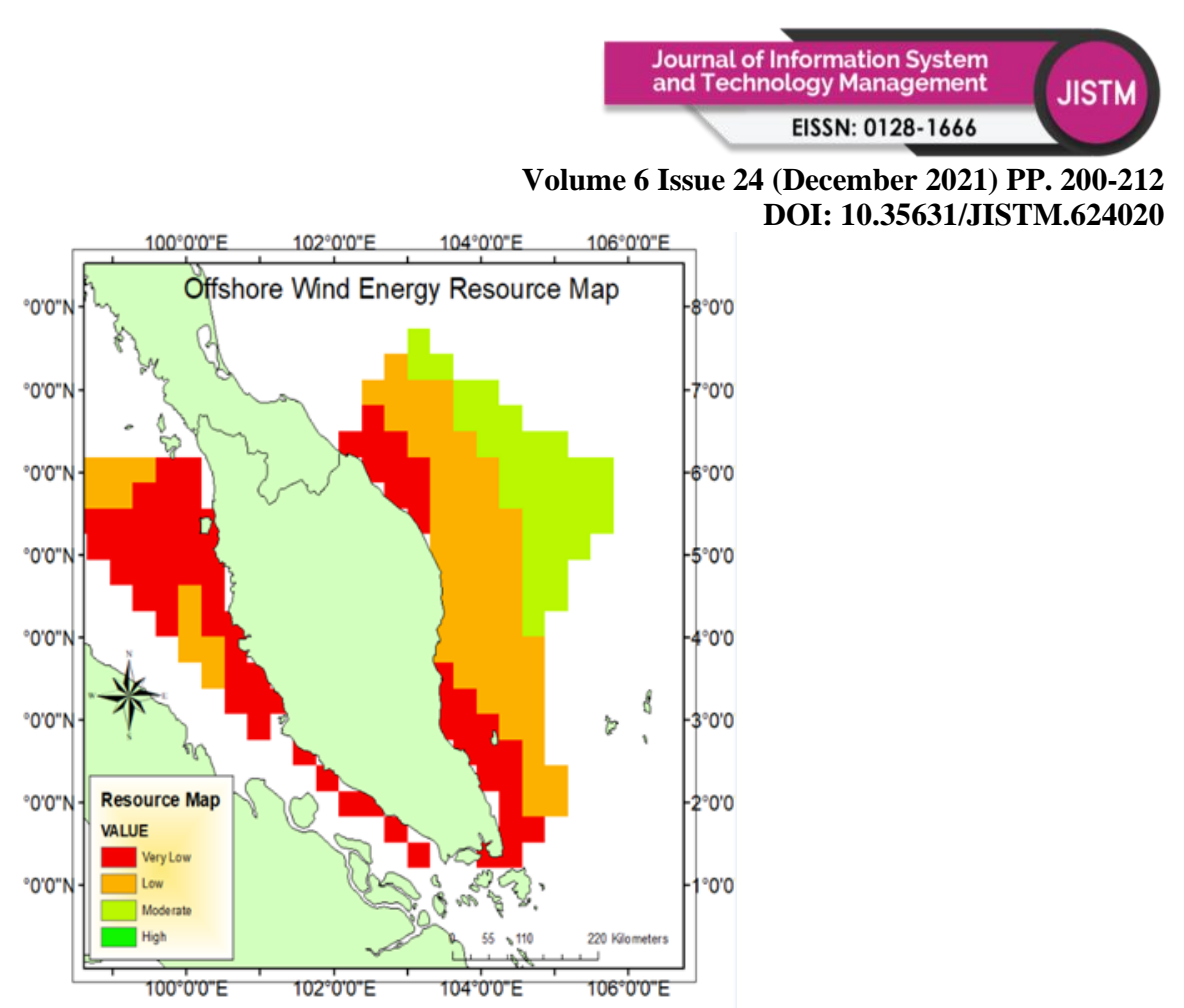

Figure 7: Resources Model

\section{Conclusion}

As a conclusion, this study proved that satellite altimeter data is reliable to provide the marine information for ocean renewable energy analysis. Theoretically, Terengganu area experienced with strong wind during the Northeast monsoon and capable to harvest up to $50 \mathrm{~W} / \mathrm{m}^{2}$ of wind power density. With the site suitability analysis, this study will support the wind farm development by providing a spatial information to government and related agencies to design suitable technology and draft a better policy for a future clean energy in Malaysia.

\section{Acknowledgement}

The authors would like to thank to TU Delft Altimetrics LLC for providing altimetry data through Radar Altimeter Database System (RADS) and the oil and gas company for providing the buoy data. This project is funded by the Ministry of Science, Technology and Innovation (MOSTI) under the International Collaboration Fund, Project Number IF1117N0008 (UTM Vot Number: R.J130000.7901.4S142) and the Ministry of Higher Education (MOHE) under the Fundamental Research Grant Scheme (FRGS) Fund, Reference Code: FRGS/1/2020/WAB05/UTM/02/1 (UTM Vot Number: R.J130000.7852.5F374).

\section{References}

Albani, A., Ibrahim, M.Z. \& Yong, K. H. (2018). The feasibility study of offshore wind energy potential in Kijal Malaysia: The new alternative energy source exploration in Malaysia. Energy Exploration \& Exploitation, 32(2), 329-344.

Aziz, W. A. W. A., Omar, K. M., Yaakob, O., \& Din, A. H. M. (2014). Ocean wind speed characteristic over malaysian seas from multi-mission satellite altimeter during monsoon periods. Jurnal Teknologi, 71(4), 79-82. doi:10.11113/jt.v71.3829

Briggs H, G. (2012). Low speed wind turbine design. IntechOpen Book Series, doi: $10.5772 / 53141$.

Hashim, F. E., (2016). Assessment of wave energy resources in Malaysia using satellite altimetry. Universiti Teknologi Malaysia

Hashim, F. E., Peyre, O., Lapok, S. J., Yaakob, O., \& Din, A. H. M. (2020). Offshore Wind Energy Resource Assessment in Malaysia with Satellite Altimetry. Journal of 
Sustainability Science and Management, 15(6), 111-124. doi:10.46754/jssm.2020.08.010

Hong, L., \& Moller, B. (2011). Offshore wind energy potential in China: Under technical, spatial and economic constraints, Energy, 36, 4482-4491.

Kumar, U. M., Swain D., Sasamal S.K., Reddy N. N., Ramanjappa, T. (2015). Validation of SARAL/Altika significant wave height and wind speed observations over North Indian Ocean. Journal of Atmospheric and Solar-Terrestrial Physics,135, 174-180.

Lozano, S., Cascales, G. M. S., \& Lamata, M. T. (2014). Identification and Selection Potential Sites for Onshore Wind Farms Development in Region of Murcia, Spain. Energy, 73, 311-324.

Lyimo, N. N., Shao, Z., Ally, A. M., Twumasi, N, Y. D., Altan, O. \& Sanga, C. A. (2020). A fuzzy logic-based approach for modelling uncertainty in open geospatial data on landfill suitability analysis. ISPRS International Journal of Geo-Information, 9, 737.

Oskamp, J.A., \& Ozkan- Haller, H. T (2011). Wave predictions at the site of a wave energy conversion array. Coastal Engineering Proceeding, 1,32.

Rahim, A. A., (2011). Potential wave energy site selection using GIS and fuzzy logic. Universiti Teknologi Malaysia.

Saaty, T. L. (1980) The analytical hierarchy process: Planning, Priority Setting. Resour. Alloc, $2,287$.

Smith, M. C. \& Wright, W. A. (2011). 13- Optimising wind turbine design for operation in low wind speed environments. Wind Energy System, 366-e388, Woodhead Publishing.

Traon, P. Y. L., Antoine, D., Bentamy A, Bonekamp, H. L. A., Breivik, B. Chapron, G. Corlett, G. Dibarboure, P. DiGiacomo, C. Donlon, Y. Faugère, J. Font, F. Girard-Ardhuin, F. Gohin, J.A. Johannessen, M. Kamachi, G. Lagerloef, J. Lambin, G. Larnicol, P. Le Borgne, E. Leuliette, E. Lindstrom, M.J. Martin, E. Maturi, L. Miller, L. Mingsen, R. Morrow, N. Reul, M.H. Rio, H. Roquet, R. Santoleri \& J. Wilkin (2015). Use of satellite observations for operational oceanography: recent achievements and future prospects. Journal of Operational Oceanography, 8:sup1, s12-s27, doi: 10.1080/1755876X.2015.1022050.

Uti, M. N., Din, A. H. M., \& Omar, A. H. (2013). Reliability of wind speed data from satellite altimeter to support wind turbine energy. Paper presented at the International Archives of the Photogrammetry, Remote Sensing and Spatial Information Sciences - ISPRS Archives, , 42(4W5) 215-224. doi:10.5194/isprs-archives-XLII-4-W5-215-2017

Vagiona, D., G., \& Kamilakis, M. (2018). Sustainable site selection for offshore wind farms in the South Aegean- Greece. Sustainability, 10,749.

Yaakob, O., Hashim, F. E., Mohd Omar, K., Md Din, A. H., \& Koh, K. K. (2016). Satellitebased wave data and wave energy resource assessment for south china sea. Renewable Energy, 88, 359-371. doi:10.1016/j.renene.2015.11.039

Yunhao, C., Danmei, H. \& Zhenjiang, Z. (2021). Low wind speed turbine design based on Wilson theory. IOP Conf. Series: Earth and Environmental Science, 621, 012175. 